Nosan, T.M. (2021). Local traditions of the Northern folk costume design of the Olonets Province from the late 19th to the mid-20th century. Scientific view on the modern problems of cultural heritage and arts in the context of social development. Klironomy, 1 (1), 54-83. Hlučín-Bobrovníky: “Anisiia Tomanek" OSVČ.

Носань, Т.М. (2021). Аокальные традиции оформления Северного народного костюма Олонецкой губернии конца XIX - до середины XX столетия. Scientific view on the modern problems of cultural heritage and arts in the context of social development. Klironomy, 1 (1), 54-83. Hlučín-Bobrovníky: "Anisiia Tomanek" OSVČ.

DOI: $10.47451 /$ her2021-05-002

EOI: $10.11249 /$ her2021-05-002

The paper is published in Crossref, Internet Archive, Google Scholar, Academic Resource Index ResearchBib, JGate, ISI, CiteFactor, ICI, eLibrary databases.

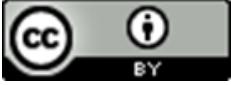

Tatiana M. Nosan

Associate Professor, PhD of Pedagogy

Department of Artistic Embroidery

Higher School of Folk Art (Academy)

St Petersburg, Russia

E-mail: TMNosan@mail.ru

\title{
Local traditions of the Northern folk costume design of the Olonets Province from the late 19th to the mid-20th century
}

\section{Abstract:}

The article is devoted to the original types of traditional design of the Northern folk costume of the Olonets Province from the late 19th to the mid-20th century. The article deals with the history of traditional folk costume, its functions: festive, ceremonial, professional, regional, class, indicating the occupation and religion. The author analyzes the materials, various methods of decorating the decor with embroidery, weaving, lace, as well as the ornament and colour scheme of the costume. The general sources of studying the history of the folk costume are works of fine and applied art, literary works and historical documents. The author concludes that the constant appeal to the modelling folk costume creativity is very important for a modern designer. The analysis of models created based on folk costume revealed various creative approaches of artists to the use of folk motifs in a modern costume created in the process of creative reinterpretation of folk traditions with regards to modern conditions.

Keywords:

folk costume, creative activity, national characteristics, folk traditions, colour scheme, cultural experience, information and aesthetic properties.

Татьяна Михаймовна Носань

кандидат педагогических наук, доцент кафедра художественной вышивки Высшая Школа Народного Искусства (Академия) Санкт-Петербург, Россия E-mail:TMNosan@mail.ru 


\title{
Мокальные традиции оформления Северного народного костюма ОАонецкой губернии конца XIX - до середины XX столетия
}

\begin{abstract}
Aннотачия:
Статья посвящена оригинальным видам традиционного оформления Северного народного костюма Олонецкой губернии конца XIX - Ао середины XX столетия. Рассматривается история традиционного народного костюма, его функции: праздничного, обрядового, профессионального, регионального, сословного, указывающая на род занятий и вероисповедание. Автор анализирует материалы, различные приёмы оформления декора вышивкой, ткачеством, кружевом, а также орнамент и цветовое решение костюма. Основными источниками изучения истории народного костюма явАяются произведения изобразительного и прикладного искусства, митературные произведения и исторические Аокументы. Автором слелано заключение, что постоянное обращение к творчеству моделирования народного костюма Аля современного художника-конструктора очень важно. Анализ моделей, созданных на основе народного костюма, выявиц различные творческие подходы худОжников к использованию народных мотивов в современном костюме, при созАании которого идет процесс творческого переосмысления народных традиций с учетом современных условий.
\end{abstract}

Клточевые слова:

народный костюм, творческая Аеятельность, национальные особенности, народные традиции, цветовое решение, культурный опыт, информационно-эстетические свойства.

\section{Introduction}

Modern artistic creativity is based on the study of trends in the historical evolutionary development of a particular field, based on which the directions of further work are determined. The result of the creative activity of designers and designers of clothing are often things addressed to a specific national motif, in which modernity is organically combined with tradition and serves as a logical continuation. The folk costume is the object of study and the basis of the creativity of many specialists. The use of folk costume traditions largely determines the position and directions when researching folk clothing. The development of clothing goes in some sequence associated with the development of the material culture of society.

The folk costume is one of the most popular and close to a person element of ethnic culture. It is a kind of code that transmits information from the past to the future. It is in traditional clothing that the cultural experience of the people is accumulated and transformed. 
Clothing forms the personal appearance, contains information about the age, gender and ethnicity of an individual, his place of residence, social status and profession.

The ambiguity of clothing is a broad research area in which the ethnic significance of the costume is of particular interest. A costume can tell about the era in which it was created, it can be considered as an element of culture, as a universal attitude of a person to the world, through which a person creates the world.

At the early stages of the development of society, a person used jewellery to display his understanding of the world. The shapes or colour relations in the costume in the leaves and skins form symbolized or repeated natural elements, imitated the animal world or biological processes and served as part of a ritual to communicate with powerful gods commanding everything in nature to have mercy and give good luck on hunting, a good harvest or health. It should say that the symbols in the costume are rooted in hoary antiquity. They appeared simultaneously with the birth of human social consciousness.

The folk costume should consider as a kind of cultural language due to the ability to accumulate traditions, social and psychological attitudes, aesthetic requests that reflect some way of life.

The word 'costume' came to Russia from France in the 18th century after Peter the Great's reforms. The very concept of a costume has been designated in Russia since the 12th century by the Old Slavic word 'attire'. Research shows that the semiotic status of the costume continued to remain very high throughout the 19th century, i.e., it met both practical and symbolic requirements. Childhood, youth, maturity, the transition from one age category to another, inclusion in the system of family ties - all this, both in previous centuries and at the beginning of the 20th century, continued to be reflected in folk clothing in a different form.

The costume includes everything that a person is wearing at the same time: a dress, shoes, accessories, a headdress, a belt and jewellery, only if all this is selected following the composition zones and the rules of harmonization.

So, a suit, which is a system of elements designed not only to protect a person from environmental influences but also to reveal his personality with the help of information and aesthetic properties, can be fully called a suit. Carrying an image and idea, it speaks about the development level of the artistic taste of its owner, his psychology, material possibilities and even about his inner state at some moments of life. 
The costume captures some characteristics of a particular culture. At the same time, it is an intermediary between the types of cultures of different chronological periods and ethnic groups, carrying out communication, broadcasting and assimilation of some information, which is significant for this culture.

Throughout the centuries-old history of its existence, the folk costume was designed to organize the space around a person. Its functionality is determined by a person to serve as a means of protecting him from the outside world. The creative source that contributes to the renewal, expansion of the assortment, and improvement of the quality of clothing is the Russian folk costume, as the richest artistic and creative source of creativity. The scientific research of scientists, art historians and specialists of traditional applied art is devoted to the traditional folk costume of the Russian North, Olonets Province: A.V. Bakushinsky, I.Y. Boguslavskaya, N.P. Bozhyeva, N.P. Burmistrova, L.A. Dintsesa, A.P. Zhuravleva, N.M. Kalashnikova, S.V. Lebedev, E.E. Knats, N.T. Klimova, A.P. Kosmenko, A.V. Kislukha, G.S. Maslova, N.A. Rodionova, M.A. Sorokinna, V.A. Faleeva and others.

The study of the traditional applied art of the Republic of Karelia, its types in regional, historical, artistic and pedagogical aspects allows a comprehensive approach to solving the problem of preserving the cultural and historical heritage of the region.

The study of the factors of the folk costume evolution not only contributes to the enrichment of scientific knowledge in costume history but also helps to present the dynamics of the development of national and Russian culture. Russian, Karelian and Veps folk costume trends combined with the regional and national peculiarities of urban culture, observed in the cities of the Russian North and the Olonets Province.

Thus, recreating different aspects of the history of the costume helps to more accurately reconstruct the historical and cultural reality, which is especially important when creating documentary and artistic works. Folk clothing from a modern perspective is a prototype of design art and design solutions.

The variety of forms, types and layers of each complex of clothing, the bright decorative artistic solutions, the originality of ornamentation and execution techniques - all these are characteristic features of Russian folk costume for many centuries.

The rich and unique collections of Karelian museums allow us to show the beauty of the compositional solution of the peasant costume, and the expressiveness of the decor of its components (hats, jewellery, shoes). 
The object of the study was professional education, upbringing and development in the field of modelling, design and technology of performing folk costume, as one of the leading directions in the field of a new direction in the modelling business.

The subject of the study was the content and methods of modelling, design and technology, taking into account historically established traditions and the modern social and cultural environment.

The purpose of the study was to update the content and methods of modelling, designing and technology of performing folk costumes of the Russian North, Olonets Province.

To achieve this purpose, the following tasks were set during the study:

- give the concept of folk costume as an element of ethnic culture on the example of the traditional costume of the peoples of the Russian North (Karelia).

- give a historical description of the northern folk costume of Karelia

- analyze the characteristics and features of the traditional festive peasant costume of the Zaonezhsk and Pudozh counties of the Olonets Province of the late 19th and early 20th centuries.

In the study course, historical, comparative and descriptive methods were applied to achieve the purpose and solve the tasks.

The study used scientific works and works of specialists in the cultural heritage and folk-art preservation N.M. Kalashnikova, R.B. Kalashnikov, L.V. Kislukha, M.I. Shumilova, etc.

\section{Folk costume as an element of the ethnic culture of the Russian North (Karelia)}

Numerous monuments of peasant art have gained the glory of folk culture and its national traditions in the Republic of Karelia.

Among them, a bright original element is a folk costume. It most fully embodied the extraordinary skill of Northern women from the late 18th to early 20 th centuries. The ethnographic orientation of the Karelian museums determined the principles of the collection formation; numerous expeditions studied the folklife in Kargopol, Pudozh, Zaonezhsk and Sheltozersk and other regions of Karelia. Costume complexes, individual items, all kinds of additions are collected: hats, jewellery and shoes. 
Peasant clothing of the late 19th and early 20th centuries is presented quite fully in the collection, especially women's clothing prevails, which serves as a convincing proof of commitment to antiquity.

It should note that the shirt retained its primary importance until the end of the 19th century was worn with a skewed or straight round sundress on the straps. Girls and young women in summer wore a shirt as an independent type of clothing, belting it or putting an apron on it (Fig. 22, 23). In the shirts' design, the previously established difference in the age and marital status of women remains. They are divided into girlish (for a young woman before the birth of a child), for mature age and old women, they differed in colour tone, the number of patterns and the quality of the fabric.

The North Russian complex with several sundress types was formed and modified over many centuries under influencing regional peculiarities.

The character of the northern costume corresponded to the peasant aesthetics. In the late 19th and early 20th century, it had many variants. It still consisted of a shirt, a sundress, a belt, a headdress, shoes. Sometimes it was complemented by an apron. Clothing was closely connected with the customs and traditions of the village. Unwritten laws established what clothes to wear on weekdays, what on Sundays, on patronal holidays, for a wedding, on the occasion of mourning.

The everyday suit was comfortable and durable. Its most archaic part was a shirt with gussets that did not restrict movement. Regional differences can be traced to the example of Kargopol, Pinezh, Vologda shirts (Fig. 26).

The oblique sundress on armholes or wide straps is the most ancient type, until the beginning of the 20th century, which existed in Pinega, was adjacent to the later straight sundress, common in other regions of the region. The front and back sundress panels were connected on the sides with additional wedges. The straight front panel did not have a median seam. The collar and armhole were cut out of a straight piece (Fig. 21).

A straight or round sundress was sewn from several straight canvases (from 4 to 7). From above, the excess fabric was collected in a small assembly and closed with a narrow ribbon or a label. On the back, narrow short straps were sewn together, and in front - separately. Ornaments in the form of decorative embroidery, braid and the like were made on the hem and the chest (Fig. 24). It was worn by the young and the elderly. The difference was that the young sewed from light fabrics and the elderly - from dark ones. 
The oblique sundress with a slit in the front with buttons and loops consisted of strongly bevelled wedges that expanded the clothes. The front section was decorated with calico with embroidery, fringe, buttons (Fig. 9). This type of clothing was widespread in the 19th century in all provinces of the central regions of Russia. It was called feryaz (from Arabic färäğä) (Fig. 15).

A sundress with a cut-off bodice appeared in the late 19th and early 20th century and was like a semi-dress. It was a straight skirt in an assembly to which a sleeveless bodice was sewn with a zipper in the front and a small cutout at the neck. Another kind of it was the bodice fitted only the back, and straight panels fell to the chest in front (Fig. 10). The artistic features of the design of Karelian sundresses were most fully expressed in the colour and ornamental solution, achieved by a harmonious combination of embroidery, sewn coloured strips of fabric, purchased braid and braid (Fig. 25).

By the end of the 19th and beginning of the 20th century, it was characteristic to replace complex labour-intensive embroidery, which played a leading role in the design of shirts and sundresses, with a simpler decorative finish of colourful calico.

For the manufacture of everyday sundresses, coloured fabrics, i.e., a checkered or striped fabric, woven from yarn previously dyed in different colours, were used (Fig. 11). The material for everyday clothes was linen, coloured fabrics, and stuffing. Later they were replaced by calico.

Clothing carried not only utilitarian and aesthetic functions. Echoes of ancient pagan ideas about the world are preserved in the costume. Clothing protected a person from the external environment, and every detail of the ensemble had some meaning. Labour holidays played a significant role in the peasants' life: harvest, the first pasture of cattle, haymaking. The well-being of a peasant family depended on them. Linen Kargopol shirts with archaic embroidery, harvest popodolitsa (women's sloping suit of the Olonets Province) are of great value in the collection (Fig. 28). The magical signs contained in the patterns of the ornament, according to the ancestors, strengthened the protective role of clothing, served as a tribute to the nurse-earth. A protected role was played by a belt made in various manufacturing techniques that existed in the North.

The most expressive in the artistic and figurative solution is festive clothing. The suit retained the traditional cut, but it was sewn mainly from more expensive, purchased silk fabrics. He was more influenced by the city. The festive folk costume of the Olonets Province at the end of the 19th century is extremely beautiful in colour and unique like the decorative design (Fig. 14). With the spread 
of factory cotton fabrics, wider and softer, shirts began to be cut without poliks, i.e., cut details connecting the shelf and the back along the shoulder line (Fig. 29).

In the peasant environment, a voluminous, non-poly shirt appeared. Sometimes such new-cut shirts from factory fabrics were made composite: the upper part was sewn from calico, calico or coloured fabrics, and the lower part the mill - was sewn in an old-fashioned way from the canvas. Later, under the influence of urban fashion, the composite shirt was divided into a jacket and a skirt (Fig. 30). In turn, the sundress was transformed into a clothing type, close to the city dress in tailoring during the 2 nd half of the 19 th century.

Thus, the social structure has always been an intensive search for new ideas allowing us to anticipate their further development. So, the folk costume is not only a bright original element of material culture but also a combination of various types of decorative creativity, preserved the characteristic traditional elements of tailoring, ornamentation, use of materials and decoration.

\section{History of the Northern Karelian folk costume}

The cultural heritage of the Northern people, accumulated over the centuries, is great and diverse. The products that have come down to our times allow us to judge their high artistic significance, made by the hands of masters. Such is the clothing, passed a long way in its development, closely connected with the history and aesthetic views of its creators.

Peasant clothing most of all retained the features inherent in the national costume in the past. It is because the ruling classes of Russia had to switch to the mandatory wearing of European-style dresses by the decree of Peter I since the early 18th century. Since the reform did not affect such a huge layer of society as the peasantry, it is the peasant costume that becomes truly popular.

The formation of the composition, cut, and features of the ornamentation of the Russian folk costume was influenced by the geographical environment and climatic conditions, the economic structure and the level of development of the productive forces.

An important factor was the historical and social processes that contributed to creating specific forms of clothing, the role of local cultural traditions was significant. The vastness of the settlement territory, the isolation of individual places, the different natural environment and raw materials, the nature of customs and living conditions were the reason for the emergence of various clothing options. So, in women's clothing, not excluding the abundance of its types and types, two are distinguished: a shirt with a sundress with a magpie headdress, a shirt 
with a sundress and a kokoshnik. The complexes differed in their components, features of the cut and decor from each other (Fig. 13).

The evolution of the costume in the folk environment was slow, yielding little to external influences.

By the early 20th century, the most common were: a complex with a sundress, the North Russian, which existed in the Russian North consisted of a shirt and a long sundress. The complex of a skirt with a jacket also became popularly (Fig. 4).

Over the sundress, they wore a shower jacket - a short chest garment with straps, in the cold season - a shugai in the waist with sleeves and a collar. With such a costume, girls wore a headband or a crown, and married women - a onepiece rigid headdress kokoshnik (Fig. 20).

The folk costume division into everyday working, festive and ceremonial was observed. Such clothes were always newer. They were more often made of expensive fabric, made up of numerous items, and decorated more abundantly. Festive clothing also had its regulations. One was worn on Sundays, the other on large, so-called 'annual' holidays (Fig. 8).

Directly adjacent to it are ceremonial costumes' variety: a betrothed girl, a wedding, a funeral (sometimes it is also a wedding) and others. It is characteristic that a harvest shirt was decorated as lavishly as a festive one (Fig. 27). Ceremonial clothing retained its ancient forms longer. Festive clothing was more often influenced by fashion, especially urban (Fig. 1, 2). Everyday costume for housework and in the field was made of durable fabrics and ornamented more modestly. Clothing has always emphasized family and age differences (Fig. 6; 7). The children's costume was less complicated in execution and was made of more affordable material.

There is a social moment in the composition and use of decorative materials in folk clothing. In the wardrobe of a well-to-do northern peasant woman, there were brocade sundresses, fur-trimmed soul guards, headdresses decorated with pearls. In poor families, homespun prevailed, textiles, small river pearls, glass beads, beads, bird down and dyed feathers were used as decoration (Fig. 12).

The described complexes, developed and existed for many centuries, were subjected to changes in the cut, material and ornamentation in some cases.

So, in the second half of the 19th century, a shirt on a yoke, a sundress 'Moskvich' (Muscovite), a half-dress appeared under the urban influence (Fig. 27).

Since that time, in connection with the capitalistic development in the countryside, the Russian peasantry has been experiencing a class stratification process, affected its everyday way of life and clothing. The light industry 
development, the flourishing of the factory cotton fabrics' production, the growth of the craft led to the transformation of women's costumes, consisting of a skirt with a jacket or a dress.

It applies primarily to the central industrial regions of the country (Fig. 37). These changes were intensively occurring both among the poorest and richest peasants. The sundress was preserved in remote and closed areas of the Russian North.

The clothing of the male population of the Russian North, in comparison with the female, was less diverse. Its main parts were a shirt, ports, a belt (Fig. 16). As a rule, they were sewn from linen, hemp, woollen fabrics of home manufacture, and from the second half of the 19th century - more often from factory fabrics. Compared to the multi-colour and multi-component women's ensemble, the men's suit was much simpler and calmer in its colour and decorative solutions. However, in the most solemn moments of life, shirts with various decorations were used in them (Fig. 17).

The predominance of deaf tunic-like and wide straight swing clothes reveals the desire to create a massive, slightly dissected form, a solid and extremely simple silhouette in the pattern. Massiveness, as a rule, increases downwards, which is emphasized by shoes - woven bast shoes, large boots in the assembly and heavy shoes, which were sometimes worn on seven or eight pairs of thick woollen stockings.

The waist in a traditional women's suit is not emphasized but is hidden by all sorts of bibs. Of great importance is the headdress, which strongly accentuates the face.

The preferred colours are white and red, but the clothes of wealthy northerners, usually made from purchased expensive fabrics such as damask and semi-brocade, in which great importance is attached to the shine and shimmer of gold and silver threads, the iridescence of mother-of-pearl and pearls.

The intensity of the colour scheme had increased by the 20th century. It was partly due to the use of aniline dyes and factory fabrics. The outerwear was distinguished by the naturalness of the colour (black, brown, dark yellow, grey and blue krashenina, i.e., coarse home-made dyed fabric) and relatively little decorated. A man's suit, except for outerwear, follows the proportions and divisions of the human body.

Various removable jewellery played an important role in girls' and women's costumes: earrings, bibs, gaitans, back and waist pendants. For the northern regions of Russia, either necklace of the collar is characteristic, tightly fitting the neck and 
representing wide nets made of mother-of-pearl, pearls and white beads, or strips of canvas embroidered with the same materials supplemented with coloured glass inserts, ribbons.

For several centuries, buttons have been a traditional attribute of clothing. They were intended not only for buttoning it but also for decoration. Buttons were made of various metals and decorated in a very diverse way. In their ornamentation, engraving, black, filigree, grain, inserts of glass and stone, embroidery with small pearls and mother-of-pearl were used.

Since ancient times, a belt woven or decorated with bright embroidery, which gave special solemnity and significance to events, was considered an obligatory accessory of women's and men's costumes. A belted shirt or outerwear fits more tightly to the body, and the belt, thus, warms the clothes; in addition, things necessary for household use were attached to the belt. It could be a flint, a pouch, combs, knives, keys, needlers. Walking without a belt was considered a 'sin'.

The Karelians had some beliefs, associated with the belt that it allegedly protected from "evil spirits", served as a talisman against "damage and the evil eye". It served as a wedding gift to the groom's relatives from the bride. It was given to the sister-in-law or another relative of the husband. In peasant families, elegant belts were inherited and carefully preserved.

Festive belts differed from everyday ones in the brightness of colours and decorations. Belts of young women and girls were made the most elegant, decorated with tassels at the ends (Fig. 31). The terminology of belt patterns is currently Russian and is associated with the technique of weaving. Often there are 'patterns' of Russian letters that make up phrases: "Whom I love, I give", "I love cordially, I give forever", "My dear, do not forget to wear, I give to do not lose", "A blue-winged dove will fly up to a cute little house, give her a belt. To wear the venerable Paraskovya Raldobina, not to lose, not to stop loving, not to beg for wishes, I give someone whom I love." (Kargopol County, the village of Skopinskaya) (Fig. 32). Sometimes the words of prayer were woven on the belts or samples of individual letters were copied. The main function of the belt was to include a person in the cultural space and the manifestation of his social status. A tied belt accompanies a person throughout his life.

The belt was considered a sacred object because it was given to everyone at baptism. The belt carried a powerful layer associated with the theme of fertility, sexual strength, childbearing, etc. It was a strength symbol when applied to the masculine principle in man and a symbol of virginity when applied to the feminine. 
The belt ritual significance in the traditional culture of the Russian North, Karelia, has been preserved to this day, especially among the Old Believers.

The basis of the traditional men's costume of the 19th-century Northern Karelians was shirt and trousers made of thick canvas at home. Researchers regarded it as the influence of the Finnish tradition. The composition of the men's costumes everywhere included a shirt, ports (trousers), a belt, shoes and a headdress. Everyday clothes were sewn from homespun checkered or striped coloured fabrics or padding, and at the same time, they were almost not decorated.

The men's suit also includes caftan-type outerwear (Fig. 19). The clothes of the simple and rich people were distinguished by the dignity of the material and decoration. Men's kosovorotki and fur coats were belted with narrow and wide belts. Many men used narrow fabric belts with small geometric ornaments. North Karelians' trousers were sewn from grey homemade thick cloth.

Any peasant costume was necessarily complemented with shoes, woven or leather. Like outerwear, shoes were almost the same for men and women and differed only in size and jewellery. Its most common type was Russian oblique bast shoes of various types made of bast or birch bark.

The most primitive were pistons, sewn from one or two pieces of leather and fastened to the leg with straps or ropes threaded through the slots. Pistons were working shoes. In the late 19th and early 20th centuries, they were worn in the northwest and south of the country where bast shoes were not widely used.

Women's leather shoes compared to men's were more decorative and structurally diverse. Typical for the southern regions, 'cats', i.e. women's shoes such as ankle boots, were worn with stockings and braids. Cats are solid leather shoes with rounded or trapezoidal noses, with high heels. Unlike everyday shoes, they have always been richly ornamented with appliques of multi-coloured morocco, cloth, sequins, tinsel thread.

In addition to the costume in the cold season, women had knitted thick wool and thread stockings, plain, striped or patterned. Girls of marriageable age, as a rule, wore several pairs of such stockings at the same time to make their legs look fuller since fullness was the general measure of peasant beauty among the people.

In winter, felted shoes were worn, e.g., felt boots and wire rods, which appeared at the early 19th century. In the Russian North, fur shoes were worn.

Throughout the 20th century, huge changes took place in the country. The development of the economy and culture had a strong impact on the costume. Today, throughout the territory of Karelia, the population wears urban-style clothing, made mainly by factory methods because the development of the textile 
and light industry and growth of prosperity led to the disappearance of the traditional national costume.

However, even today, mainly in rural areas, in some areas of the North, there are complexes of folk clothing that are carefully stored and worn for weddings and festive festivities. To a large extent, the folk costume is used in folklore ensembles and amateur performances. Fashion designers often turn to it, creating samples of modern clothing.

In cold weather, Russian women wore a shower jacket. It was a short loose jacket, gathered in the upper part in small folds, which, like the sundress, was held on the shoulder straps (Fig. 20).

In the northern regions, the soul guards also had the names 'korotena', 'feather', 'epanechka', sheepskin coat. The shower shelves were straight. There were tubular pinches on the back (Fig. 3 a, b). At the top, it had a figured cutout with a cape, to which straps were sewn. The shower jacket was very lush in the lower part and only slightly covered the waist. It was worn over a sundress and a shirt, sewn from expensive patterned fabrics and trimmed along the edge with a decorative border. Especially elegant were the soul guards made of crimson velvet, thickly embroidered with braid or gold thread. The soul guards were part of the festive set of clothes. They were typical for residents of rich villages, as well as townspeople and merchants. Swinging shugai (such as a jacket) with sleeves were quilted on cotton wool, a large turn-down collar and sleeves were trimmed with metal fringe or inexpensive fur. Jackets 'fur coats' were sewn from expensive silks and furs (Fig. 18). Mainly from homespun and calico, armbands were made - sleeves with a jumper, characteristic of everyday clothing. Being an original national dress, soullivery often returned to the fashion of later times. In the northern regions, soul guards, which were also called 'korotena', 'epanechka', sheepskin, were made of brocade or scarlet velvet, embroidered with braid or gold thread.

\section{Traditional festive peasant costume of Zaonezhsk and Pudozh counties of Olonets Province (the late 19th and early 20th centuries)}

The Zaonezhans, who live beyond Lake Onega, on the territory of the Zaonezhsk Peninsula with the inhabited islands adjacent to it, have become a numerous and preserved territorial group of Russians.

The richness of details of the festive women's Zaonezhsk costume: (muslin sleeves, pearl necklaces, scarlet ribbons, woven with gold threads, silk shawls, brocade sundresses), indicates that the Zaonezhsk costume dates back to the 18thcentury boyar costume, consisting of a shirt, a sundress, a shower jacket and a 
headdress. The specificity of the traditional peasant costume was associated with the aesthetic ideas of the peasants about female beauty.

A woman of strong physique, healthy, capable of hard physical labour was considered beautiful, and the traditional costume fully corresponded to this aesthetic image.

Loose-fitting clothes with individual details and an abundance of folds on the back of the sundress gave the female figure a special significance.

Folklore collector P.N. Rybnikov described a Christmas conversation in the village of Shunga in the 1860s: "The rich are dressed in red brocade and damask sundresses, tied at the waist with a belt of ribbons, and thin shirts with Polish (short) sleeves. On their necks, they have colourful scarves that do not cover the pearl necklace; in their ears are large pearl earrings; on their head is ahem, i.e., a net of horsehair, made of pearls, which frames the forehead like lace and goes down to the ears. The bottom consists of several lace fees, and the richer the girl - the more fees in the grid. Some have a bang, i.e., a crown made of pearls, in addition to a net" (Kalashnikova, 1999).

No less picturesque are the guys in blue caftans and undercoats, and "boatmen, i.e., those who go to St Petersburg to work, have discharged themselves in long frock coats and even in a pal-merston coat" (Rybnikov, 1989-1991).

As follows from the description, the basis of the festive women's Zaonezhsky costume was a shirt and a sundress. Festive shirts were made of thin material, factory cloth, muslin. At the collar, the shirt was gathered on the counter, the sleeves were lush with a frill trimmed with lace. Since the mid-19th century, short (Polish) sleeves up to the elbow have become fashionable (Mainov, 1877), which girls tied up with ribbons when going for a walk. Since the 17th century, 'round' or 'straight' sundresses have been replaced by oblique wedge ones.

They consist of several pieces of fabric sewn together and assembled into a fold under a small covering. Festive sundresses were sewn from damask or brocade, wool, as well as blue factory cloth, known as French (Mainov, 1877). On top of the sundress, a shower jacket was put on loose clothing made of elegant fabric (most often brocade), held on straps that converged from behind to the centre of the back. The showerhead back was laid with huge tubular folds. A thin silk handkerchief was thrown over the shoulders. Its ends were removed behind the sternum of the soul-killer. In addition to the festive costume, there were pearl necklaces, pearl brooches. A handkerchief or a shower head was pinned on the chest, gold bracelets, rings and rings with them. The old festive outfit of girls 
(sundress, shower jacket, netting) was considered a bride's costume in the second half of the 19th century (Kalashnikova, 1999; Kuznetsova \& Loginov, 2001).

This tradition was preserved until the 1930s. In the early 20th century, girls wore a full suit on big evenings (Tuesday, Thursday, Sunday). Pearl jewellery and ribbons were not worn on small evenings (Friday, Wednesday) (Kalashnikova, 1999).

There was also a local fashion: in the 1920s, in the vicinity of Kizhi and Sennaya Guba, girls wore white sundresses and red shirts for big evenings. The colour of sundresses also differed on big church holidays: red for Christmas, white and blue - for Easter, green - for Trinity (Kalashnikova, 1999).

Another kind of festive costume of Zaonezhye, which appeared in the late 19 th and early 20th century in the village under the influence of urban culture, was a couple of dresses (Fig. 38).

The pair consisted of an elongated skirt and Cossack, a short-fitted blouse, trimmed at the bottom with a peplum with puffed sleeves narrowed to the wrist (Kislukha, 2006).

A significant role in the spread of urban fashion was played by the development of the clothing industry, home sewing machines' invention and the appearance of aniline dyes that reduced the cost of fabric colouring at the late 19th century (Fig. 35).

Men's festive peasant costume of the late 19th and early 20th century consisted of a cloth caftan or jacket, cloth ports, vest, shirt, neck scarf and headdress (hat or cap). Holiday boots were always worn black from chrome leather. On weekdays, "boots are always chosen made of white leather, which, according to residents, never gets wet, and black leather is worn, and you will not see anyone in boots made of black goods until the holiday when you cannot do without it to walk along the street" (Mainov, 1877).

The Zaonezhan men were dapper and liked to dress up to spend holidays. According to the apt remark of V. Mainov, Zaonezhan "peasant is ready not to eat, just to make money for a new one" (Mainov, 1877).

The description of P.N. Rybnikov also testifies to the specific panache of the Zaonezhan guys on holidays: "The guys were placed from the red window to the honourable corner... They are wearing blue caftans and undercoats, and the boatmen, i.e., those who go to St Petersburg to work, have discharged themselves in long frock coats and even in a Palmerston coat" (Rybnikov, 1989-1991).

It follows from the above: the men's festive costume of the late 19th and early 20th centuries has undergone significant changes under the influence of urban 
culture. It was a consequence of the social and economic situation of the peasant in the 19th and 20th centuries, associated with the departure to large cities, especially to St Petersburg. The Zaonezhan woman continued to remain the guardian of the way of peasant life. Therefore, the women's costume at the beginning of the 20th century continued to preserve its traditional appearance and was less changed than the men's.

The Zaonezhan women's costume preserved in its appearance the aesthetic image of a woman of Ancient Russia and the features inherent in the boyar costume of the 17 th century. Through a couple of dresses, it joined the new bourgeois culture of the second half of the 19th century.

The men's festive costume has preserved only the basis of the Old Russian costume - the ports and the shirt. In the rest of its features, it has completely acquired the features characteristic of the petty-bourgeois urban culture of the second half of the 19th and early 20th centuries. The Museum of Fine Arts of Karelia has 150 items of the folk costume of the 19th and early 20th centuries.

Since Russians, Karelians, and Veps have lived on the territory of Karelia since ancient times, the traditional costume of these ethnic groups reveals many common features formed due to long and close cultural relationships. The basis of women's costumes throughout the territory of Karelia was a shirt and a sundress. The shirt consisted of the lower part (stanushka) and sleeves (Fig. 34). The sundress was worn obliquely or round. Young girls and women preferred lightcoloured clothes; mature women wore darker clothes. The outfit of a girl, young married woman and mature woman, additionally to the colour scheme, differed in the shape of the headdress. Russian clothes in Zaonezhye differed from those worn by Russians in Pomerania, and the costume of the Olonets Karelians differed from the White Sea ones (Fig. 33). The differences were in the details of the cut, the width or length of the sleeve, in the decoration of the costume, in the hats.

The festive costume of a young girl from the Pudozh County consisted of a shirt and around sundress. A long women's shirt of the late 19th and early 20th centuries was sewn from two parts. The upper part was made of white cotton with red polka dots, and the lower part was made of four straight canvas panels. The sleeves were 'gathered' above the elbow, and the edges were trimmed with thin white lace. The hem of the shirt was decorated with embroidery in the form of a geometric ornament, a narrow strip of calico (cotton fabric painted in bright red) and lace. It was believed that embroidery, located near the open areas of the body, was not only a decoration of clothing but also a talisman. 
Around or 'straight' sundress was sewn from two elongated panels in front and three panels reaching to the waist from behind. Such a sundress was called 'with a breast' or 'front'. The narrow straps and the upper edge of the sundress were trimmed with a white braid (Fig. 5). The hem was decorated with a wide frill with white lace and embroidery located on the lower edge. The combination of the bright red colour of the sundress and embroidery, as well as the use of white lace, create a bright, festive image. The festive girlish costume was complemented by a belt and a headdress in the form of a silk ribbon or an openwork crown with a hem

Thus, the constant appeal to the creativity of modelling folk costumes for a modern design is very important. The analysis of models created based on folk costume revealed various creative approaches of artists to the use of folk motifs in modern costume when creating which there is a process of creative rethinking of folk traditions taking into account modern conditions.

\section{Discussion}

The revival and development of traditional artistic culture are fundamental in individual education, which is impossible without high works of traditional applied art.

Folk costume of the Russian North, Olonets Province, based on the execution technology, correlated with specific regional features. The development of this trend in traditional art, expressed in styles variety of modern life and high world fashion, requires the reform of professional education and the analysis of the training content in this area.

One of the most important components of understanding and preserving the historical-artistic tradition is the revival of ancient technologies. That is the renovation, which allows students to spiritually penetrate the essence of the work, master the aesthetic and cultural experience of generations, their values and achievements, recreate lost (forgotten) technological techniques of embroidery, creatively comprehend the principles of artistic heritage.

In this regard, it is particularly relevant to continue the study of the peculiarities of creating and modelling costumes of the peoples of the North, in particular, the peoples of Karelia, and in-depth work in such areas as:

1. Studying the works of art of the peoples of the North in the museum fund of local historical and cultural organizations.

2. The study of individual standard samples of the ancient Karelian folk costume to describe its structural, compositional and technological features of execution in detail. 


\section{Conclusion}

In 1900, thousands of peasants left the Olonets Province to go to St Petersburg, where they worked as carpenters, shoemakers and tailors. Several of them were widely known. Vasily Bogdanov, the Karelian from the village of Kinelakhta, Olonets Province, gained a reputation in the capital as the best tailor of the imperial house, was awarded silver and gold medals by the Russian Emperor Alexander II for his work (Shumilova et al., 2008).

The First International Exhibition of Historical and Modern Costumes was held in the Tauride Palace in St Petersburg in 1902

It was organized by the Ministry of Agriculture and State Property and was under the august patronage of Empress Alexandra Feodorovna. The All-Russian Handicraft exhibition was a genuine celebration of national labour and art. It had a wide resonance in the press. Contemporaries wrote: "The Russian capital... was amazed and amazed, contemplated the fruits of folk art. She could not have seen it, that this creativity in the exhibition, as a synthesis of folk thought and folk labour, is looking for a way out on a wide road" (Nikitin, 2004).

The Olonets Provincial Committee took part in the exhibition, which sent up to 30 women's costumes from Kargopol and Pudozh counties. For them, it received a first-degree Diploma (National Museum of the Republic of Karelia, No. 8623). The Russian North was represented by samples of costumes, embroidery, lace, towels from the Olonets 3rovince and private collections. Among the samples of urban clothing, there are products made in the workshops of St Petersburg, London, Paris, as well as sewn by local tailors of Petrozavodsk, Ladva, Pudozh at the early 20th century.

Karelia was awarded a diploma of the first degree to "the Olonets Provincial Statistical Committee for interesting costumes of the peasants of the Pudozh and Kargopol counties". The diploma gave the right to receive the 'gold' medal of the exhibition (Fig. 39, 40).

Thus, the exhibition visitors were amazed by the grandiosity of the branch of national labour, which employed a multimillion part of the rural population of Russia. Contemporaries noted that for the first time, they learned here that the products they purchased in city stores under the guise of factory products and brought from abroad, in many cases, are made by peasants of distant villages, the Olonets Province. 


\section{References:}

Kalashnikova, N.M. (2002) Folk costume (semiotic functions). Textbook. Moscow: Svarog and $\mathrm{K}$.

Kalashnikova, R.B. (1999). Conversations and conversation songs of the Zaonezhye Region of the second half of the 19th century. Petrozavodsk.

Kislukha, L.V. (2006). Folk costume of the Russian North in the collection of the State Museum Association "Art Culture of the Russian North". Moscow: The Northern pilgrim.

Mainov, V. (1877). A trip to Obonezhye and Korela. St Petersburg.

Kuznetsova, V.P., Loginov, K.K. (2001). The Russian wedding of Zaonezhya. Petrozavodsk.

Nikitin, Y.A. (2004). Industrial exhibitions of Russia of the 19th and early 20th century. Cherepovets: Polygraphist.

Rybnikov, P.N. (1989-1991). Conversations and conversation songs in the Petrozavodsk and Povenetsky counties. In 3 vols. Petrozavodsk: Karelia.

Shumilova, M.I. et al. (2008). The history of Karelia. Petrozavodsk: Karelia.

\section{Appendix}

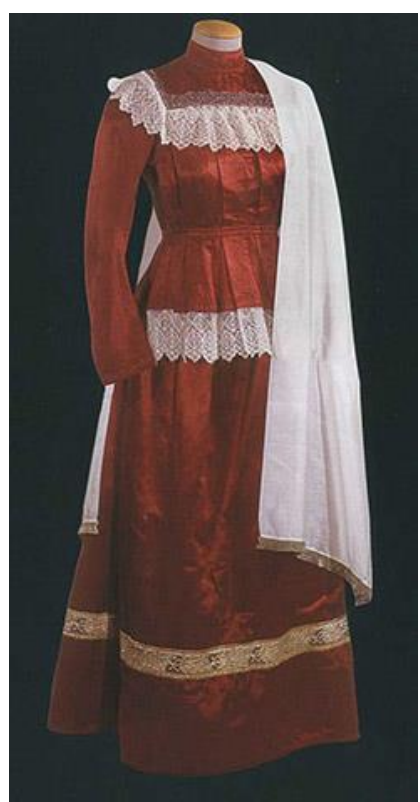

Figure 1. Festive women's costume 'couple'. The early 19th century. Olonets Province, Kargopol County. Jacket and skirt made of cherry-colored silk, satin fabric

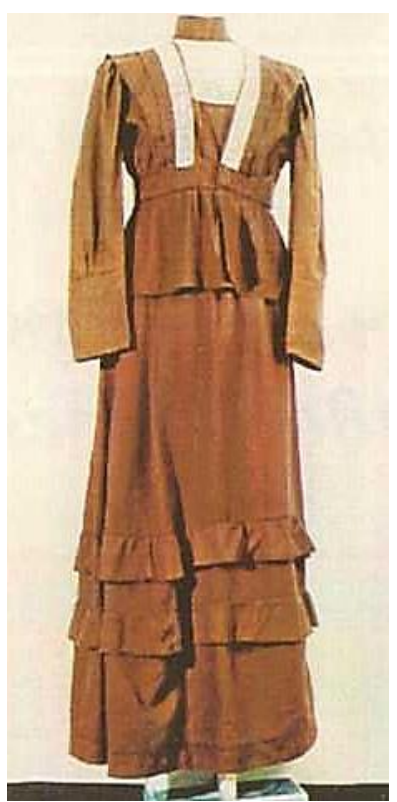

Figure 2. Festive women's Urban costume 'couple'. The late 19th and early 20 th century.

Arkhangelsk. Jacket, skirt, cotton fabric, tulle 

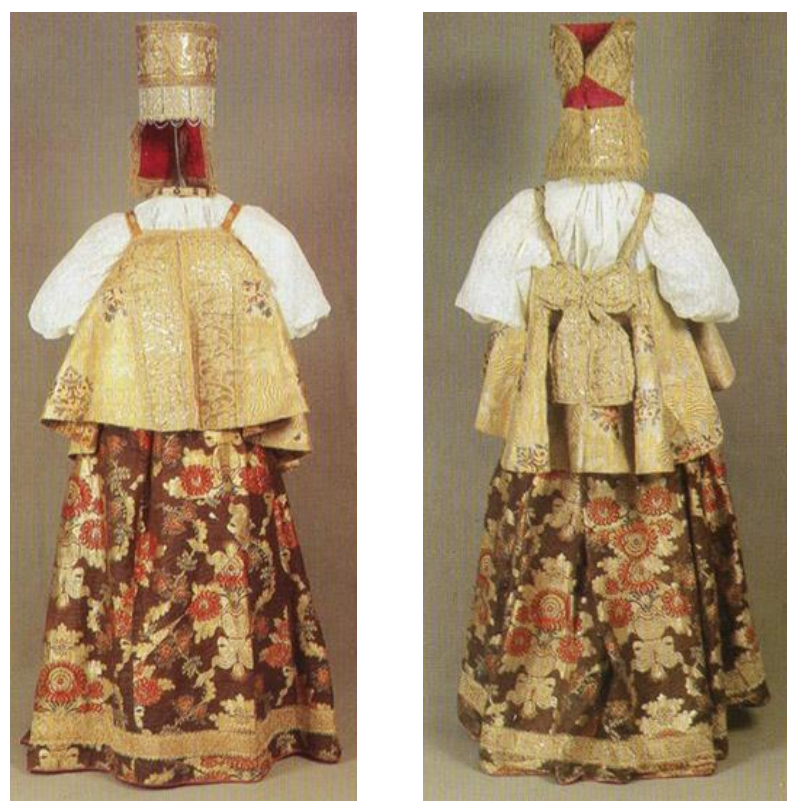

Figure 3. A girl's costume, a). Front view; b). Rear view. The late 19th and the early 20th century.

Arkhangelsk Region. Shirt: 'Collar' (shirt), muslin

fabric. Skirt: semi-parcha fabric, calico, braid, braid.

Dressing: cardboard, silk, braid, metal fringe, foil, artificial pearls, mother of pearl, sewing, knitting

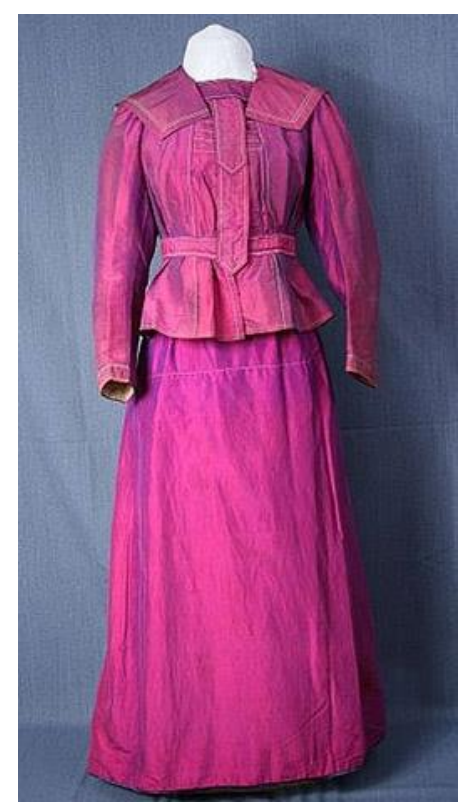

Figure 4. Vepsky women's suit. The late 19 th and the early 20 th century. Karelia, Sheltozersk Museum. It consists of a jacket and a skirt of cherry-coloured satin

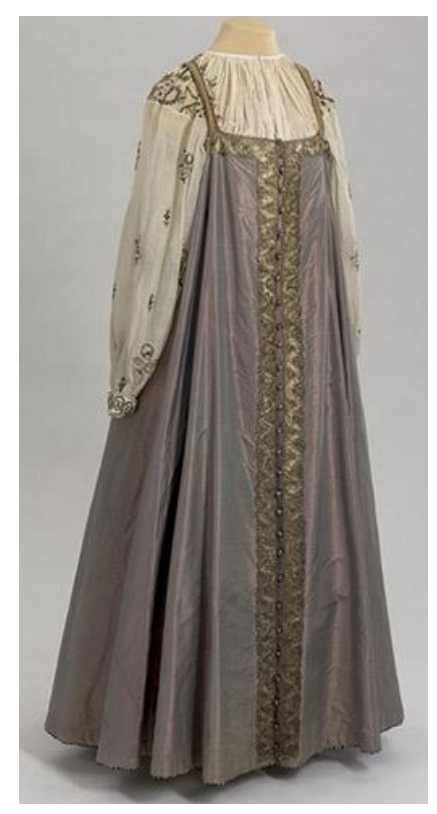

Figure 5. Women's sarafan, Northern provinces of Karelia, the early 19th century. Consists of: silk, linen, metal thread, gold braid 


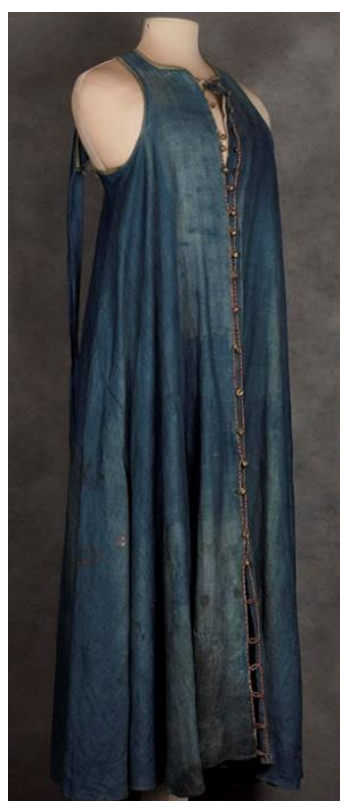

Figure 6. The sundress is an oblique-wedge swing.

Petrozavodsk. The late 18th and early 19th century. Linen fabric, copper, silk cord sewing, embroidery bodice and front floors lined with gray canvas

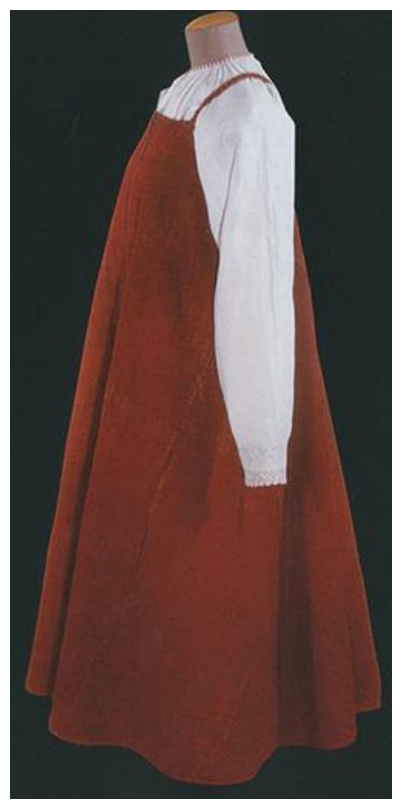

Figure 8. Wedding girl's costume: ceremonial shirt 'healer', bright red cloth oblique-wedge sundress 'ponitok'. The middle and late 19th century Arkhangelsk Region.

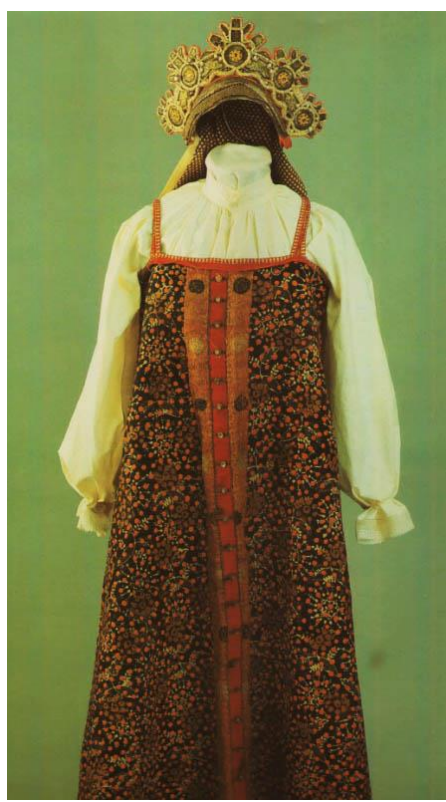

Figure 7. The costume of a young girl of the Arkhangelsk Region. The early 19th century. Shirt: cotton, lace. Sundress: linen canvas, hand-printed, girlish crown: silk, lace, coloured glass, glass beads, artificial pearls

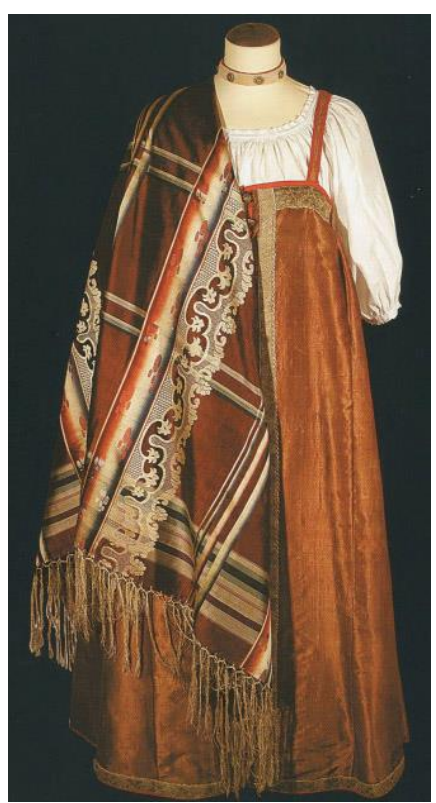

Figure 9. Festive girl's costume: 'Sleeves' - shirt: calico fabric. The sundress is oblique-wedge and swinging: the fabric is silk taffeta. The late 19th century. Olonets Province, Kargopol County 


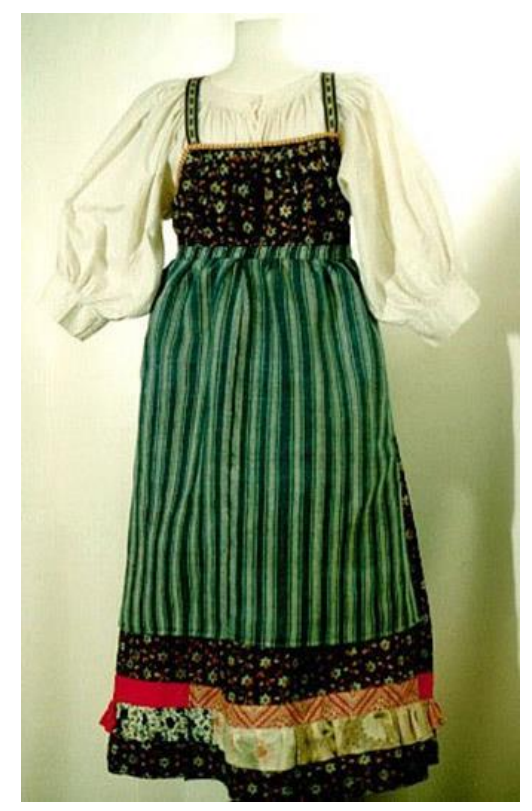

Figure 10. Women's harvest suit. The early 20th century Olonets Province, Kargopolye. Shirt, sundress: linen fabric, coloured fabric, kumach, calico, hand weaving.

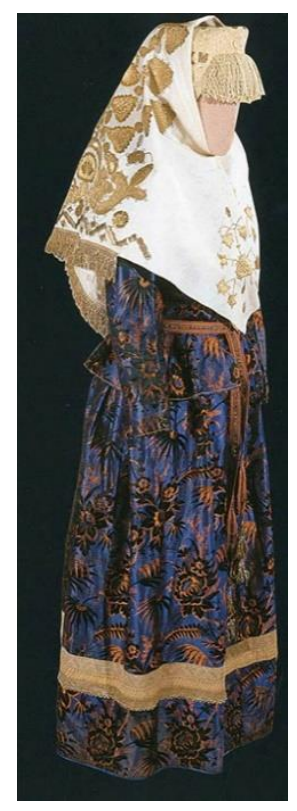

Figure 12. Women's festive costume of the early 19th century. Olonets Province

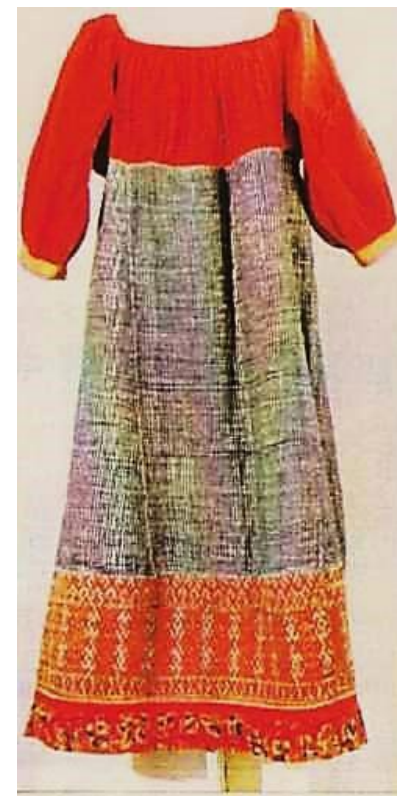

Figure 11. Women's reaping suit. The early 20th century. Olonets Province, Kargopolye. Shirt, sundress: linen fabric, coloured fabric, kumach, calico, hand weaving

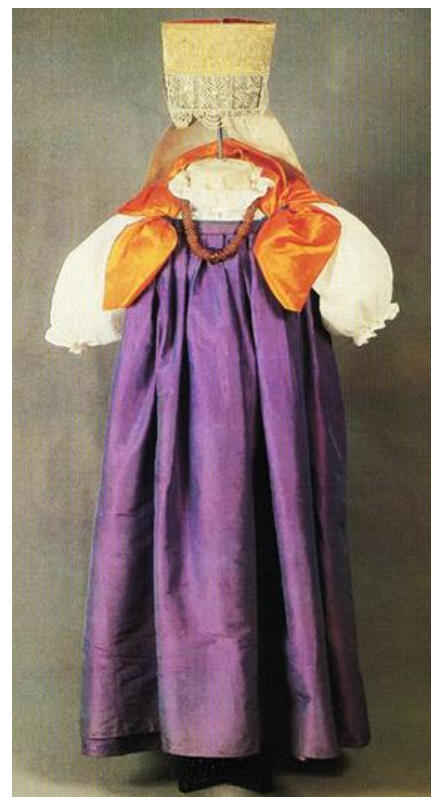

Figure 13. A girl's costume. The late 19th and early 20th century. Arkhangelsk Region 


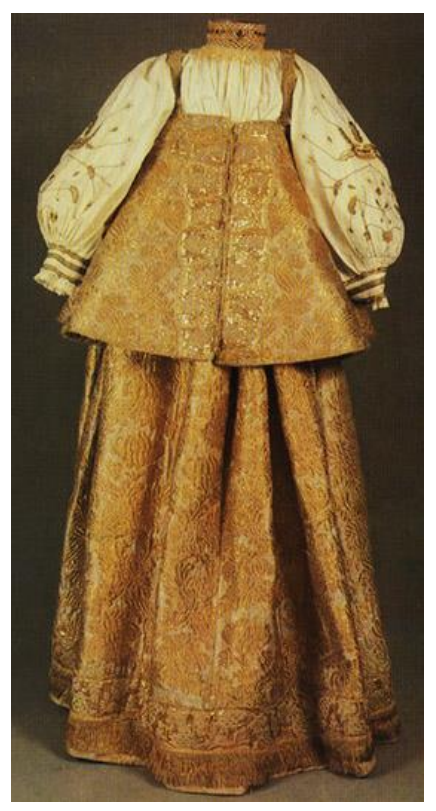

Figure 14. Women's festive costume. The late 19th century.

Olonets Province

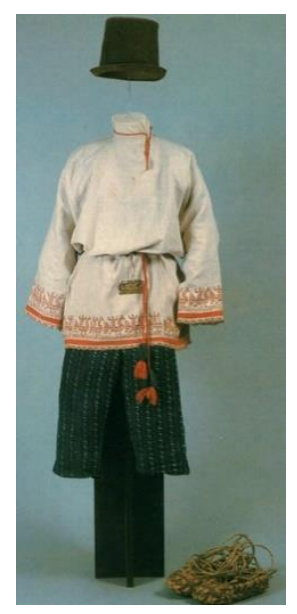

Figure 16. The suit is for men. The late 19th and early 20th centuries. Olonets Province

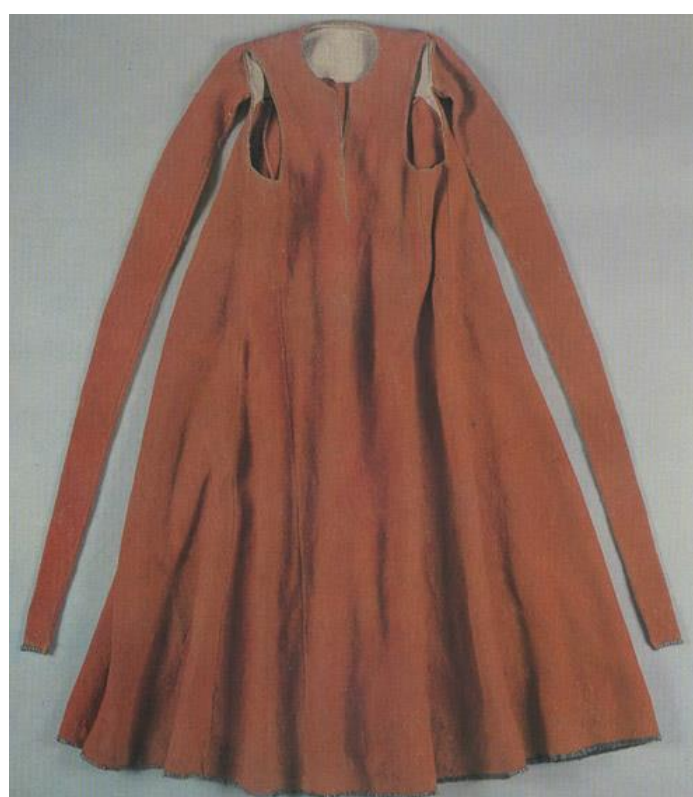

Figure 15. Feryaz. The early 19th century. Women's outerwear such as a sundress made of red, blue canvas, cloth or silk

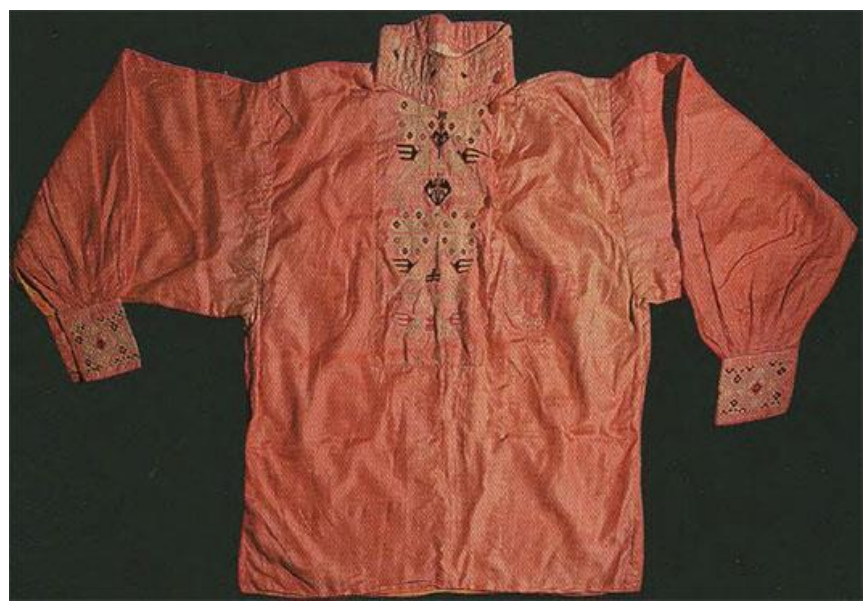

Figure 17. Men's festive shirt. The late 19th and early 20th century. Arkhangelsk Region, Pinezh County 


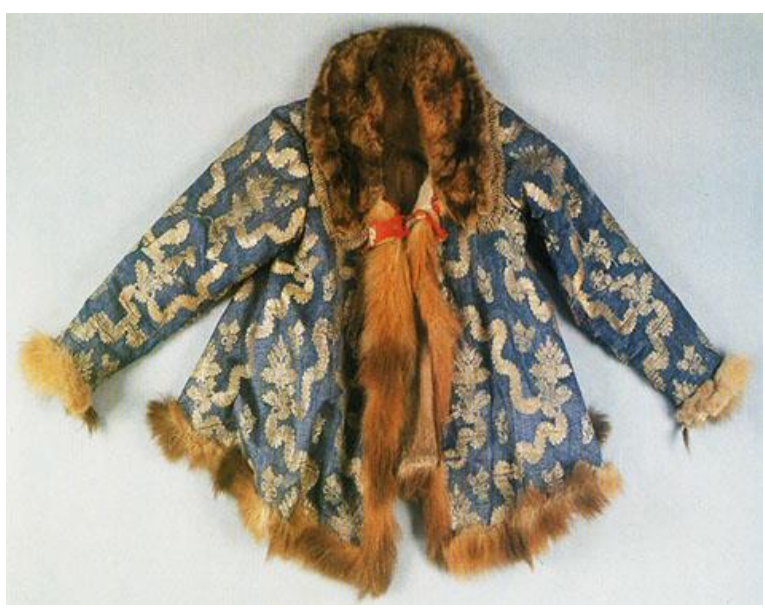

Figure 18. Women's fur coat. The second half of the 19th century. Arkhangelsk Region. Fur of sable, marten, ermine, fox, arctic fox

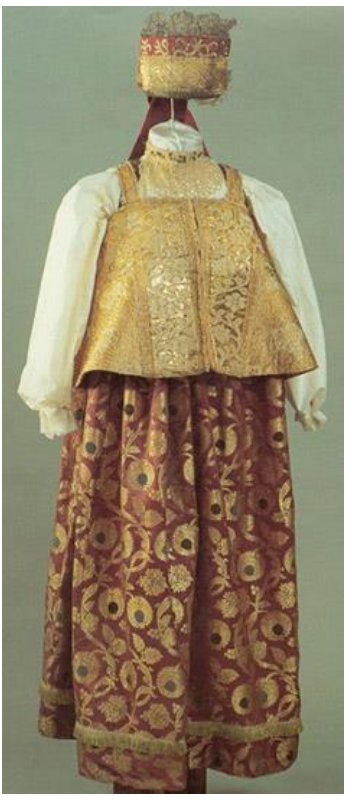

Figure 20. A girl's festive costume. The late 19 th and the early 20th century. Arkhangelsk Region. 'Collar' (shirt) made of 'muslin' fabric. The skirt is made of half-parchment and calico for lining, braid, braid. Headband (headdress): cardboard, silk, braid, foil, pearls, mother of pearl, sewing, knitting

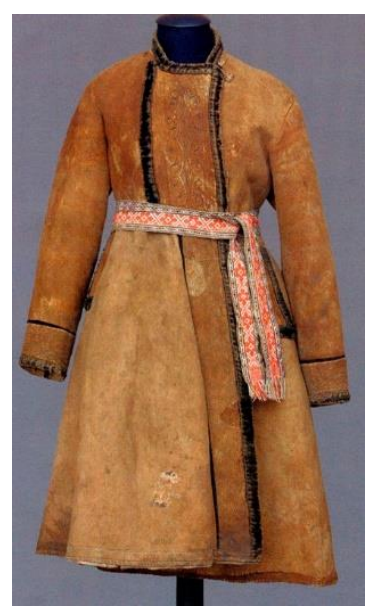

Figure 19. Zipun, i.e., unisexual outerwear. From the 17 th to the 20th centuries. Factory cloth, woven belt - sash

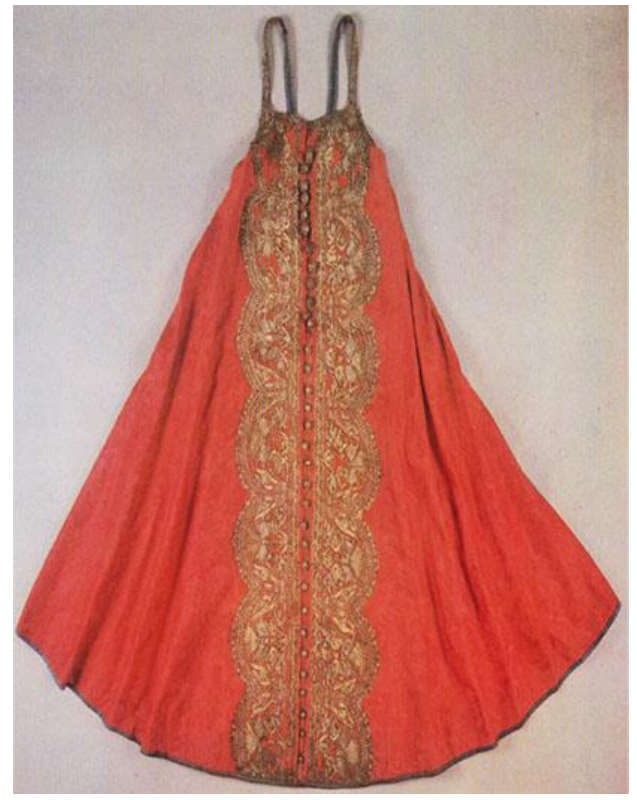

Figure 21. A festive girlish sundress of early 19th century. Olonets

Province. Kargopol County. Damask, canvas, krashenina (lining), metal lace and cord, silver buttons with embroidery 


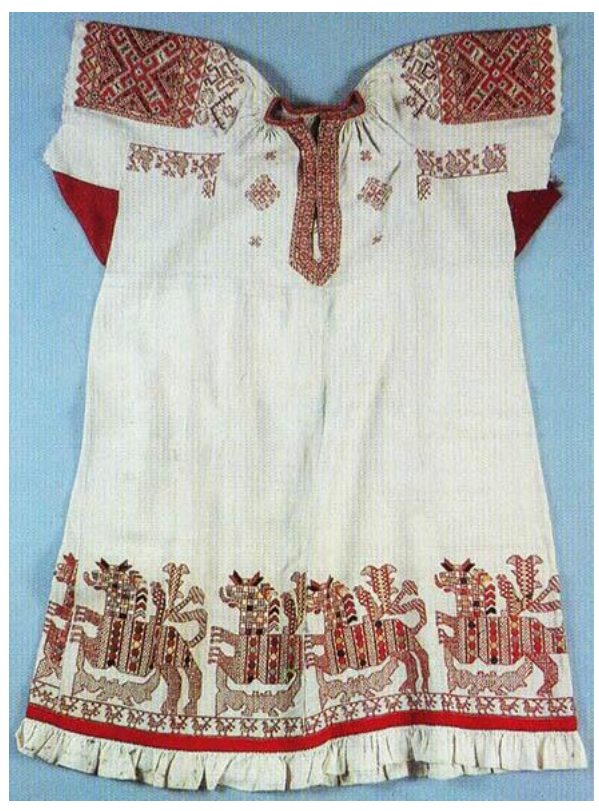

Figure 22. A girl's costume. The late 19th and early 20th century.

Arkhangelsk Region. The late 19th century. Olonets Province

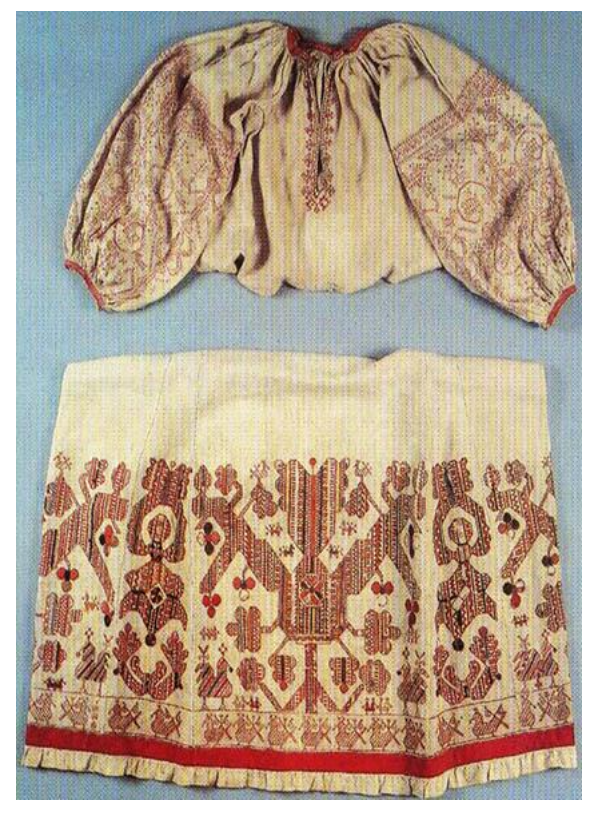

Figure 23. A girl's costume. The late 19th century. Details of a woman's shirt. The second half of the 19th century. Russian North
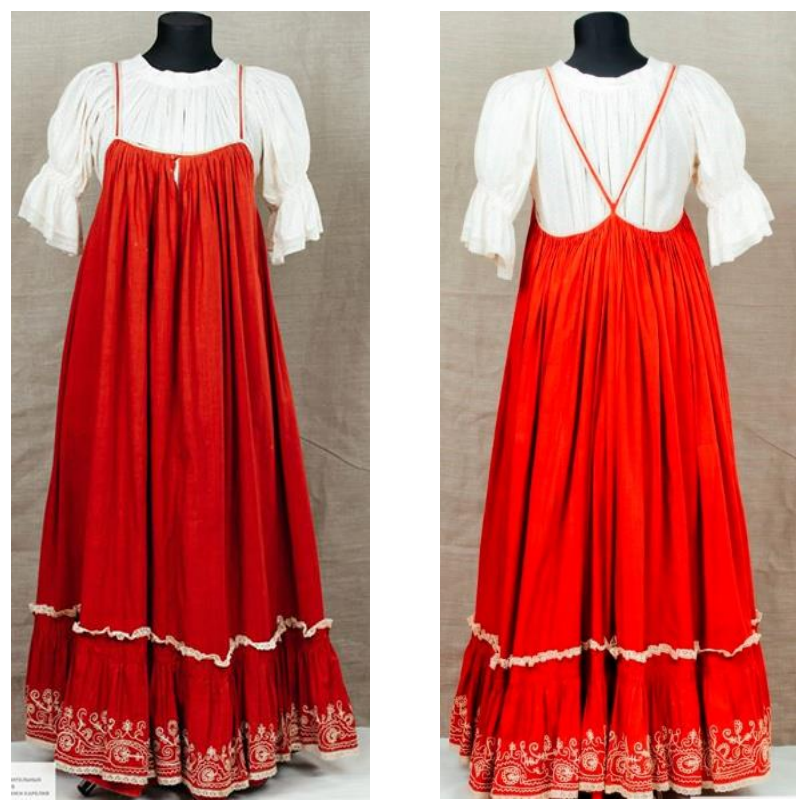

Figure 24. A festive girlish sundress. Medvezhegorsk, Pudozh County. A) Front view. B) Rear view. Kumach fabric, cotton thread, embroidery 'tambour'. The late 19th century. 


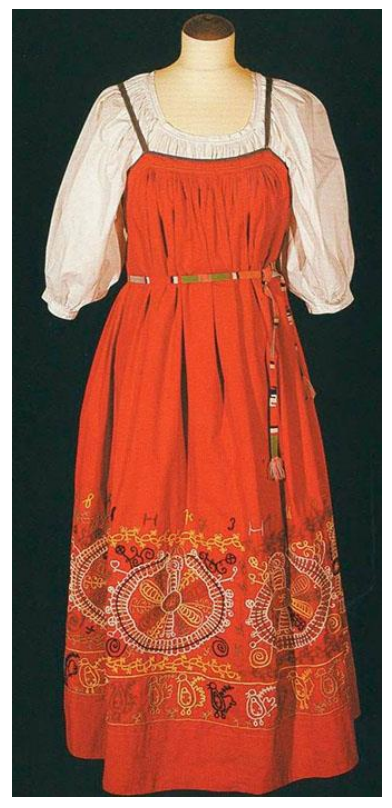

Figure 25. Women's ceremonial costume. The early 20th century.

Olonets Province, Kargopol

County. It consists of a shirt 'pokosnitsa', a sundress 'kumachnik' and a belt

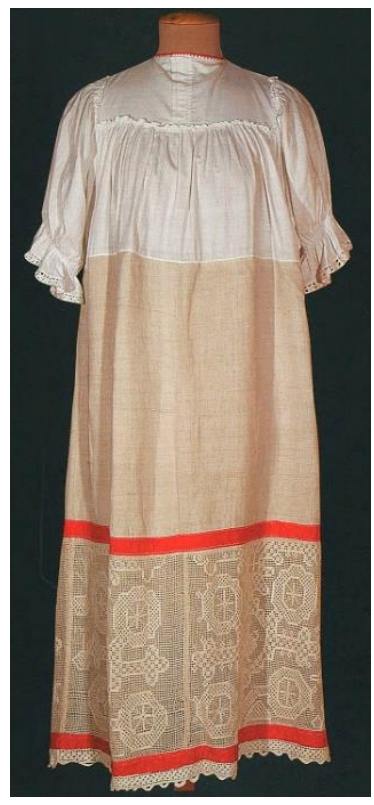

Figure 27. Shirt 'pokosnitsa'. The late 19th and early 20th century.

Olonets Province, Kargopol County.

It consists of two parts.

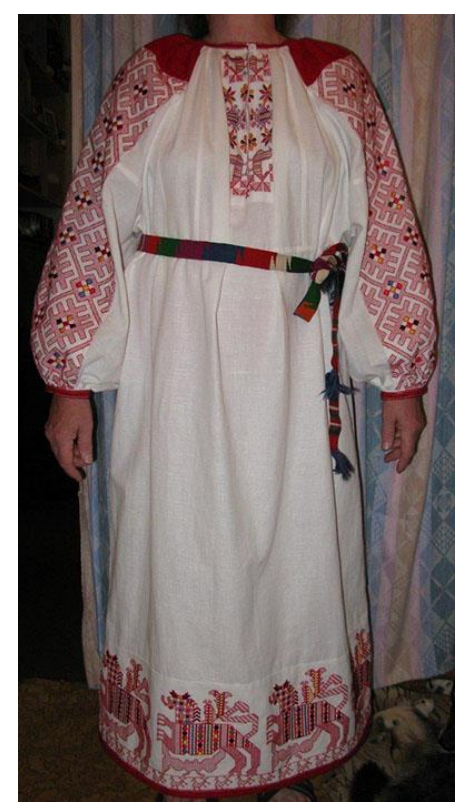

Figure 26. Women's shirt. The early 20th century. Olonets Province, Kargopol County. Olonets sewing

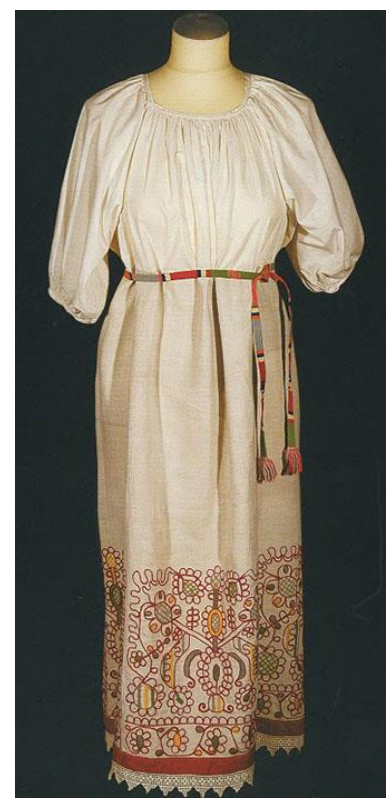

Figure 28. Shirt 'pokosnitsa'. The late 19th and early 20th century.

Olonets Province, Kargopol County. It consists of two parts. 


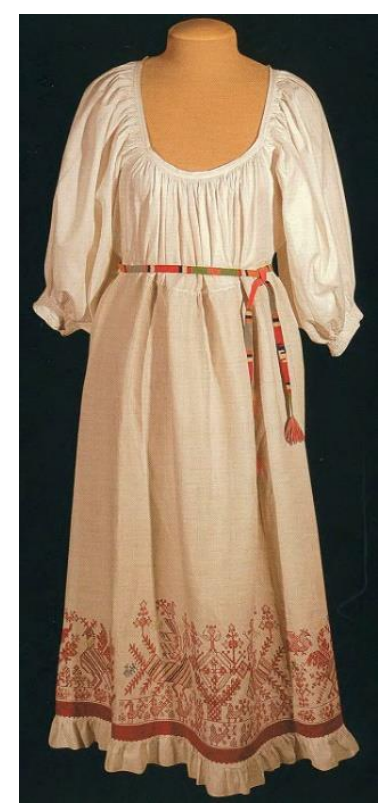

Figure 29. Shirt 'pokosnitsa'. The late 19th and early 20th century.

Olonets Province, Kargopol

County. It consists of two parts

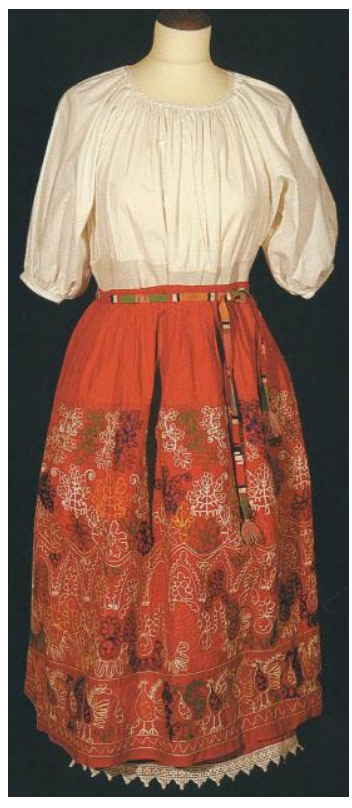

Figure 30. Skirt. The early 20th century. Olonets Province, Kargopol County. It is sewn from five straight strips of red kumach, assembled from above under a belt-strap. The hem is decorated with embroidery in the technique of 'tambour seam'

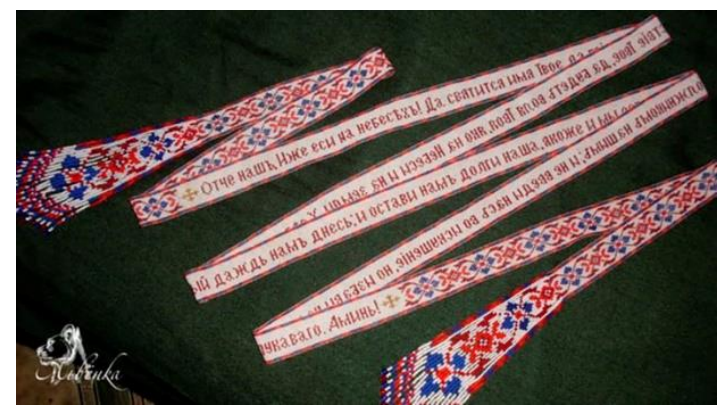

Figure 32. Woven Belt

Figure 31. Woven Belt 


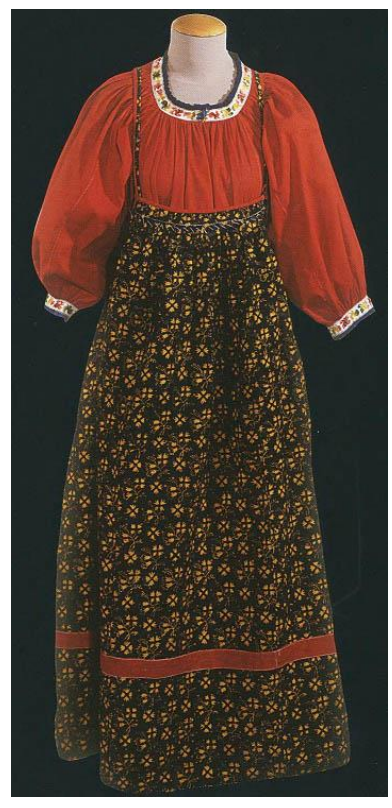

Figure 33. Festive women's costume of the late 19th and early 20th century. Olonets Province, Kargopol County. It consists of a shirt and a sundress 'nabivalnik'

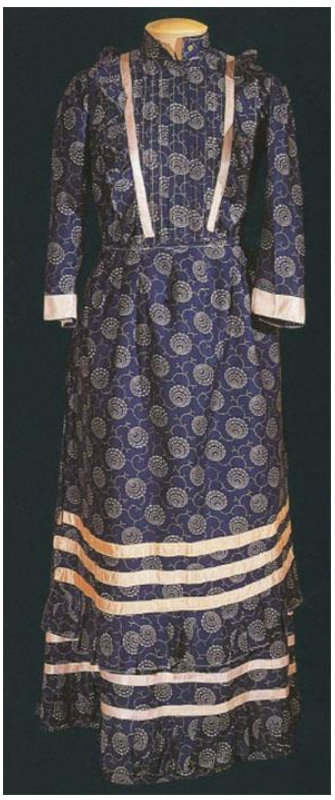

Figure 35. Festive women's costume of the early 20th century. Olonets

Province, Kargopol County, Arkhangelsk Region. It consists of a jacket and skirt made of dark blue satin with a white floral pattern

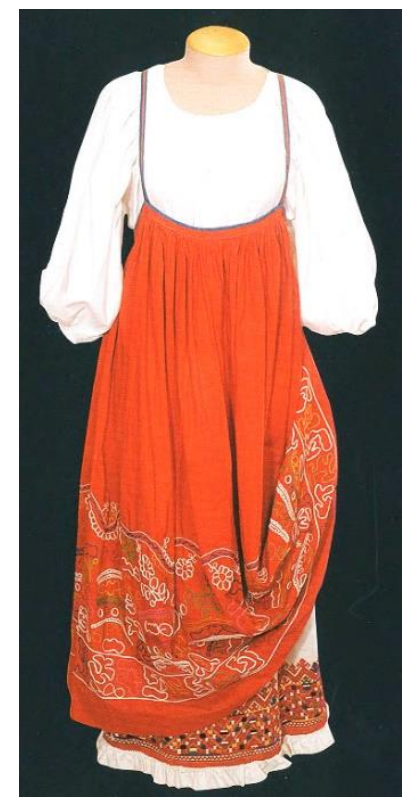

Figure 34. Women's 'sloping suit'. The early 20th century. Olonets Province, Kargopol County. It consists of a shirt 'pokosnitsa' and a sundress. The upper part of the sleeve, made of cotton fabric, calico. The lower part (the mill) is sewn from homespun linen. The hem is decorated with colored embroidery 'tambour'

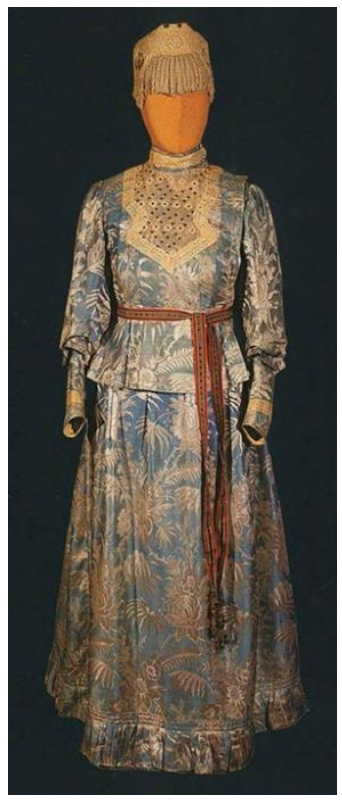

Figure 36. The costume of a young woman 'couple'. The late 19th and early 20th century. Olonets Province, Kargopol County, Arkhangelsk Region. It consists of a jacket and a skirt made of blue silk jacquard fabric 


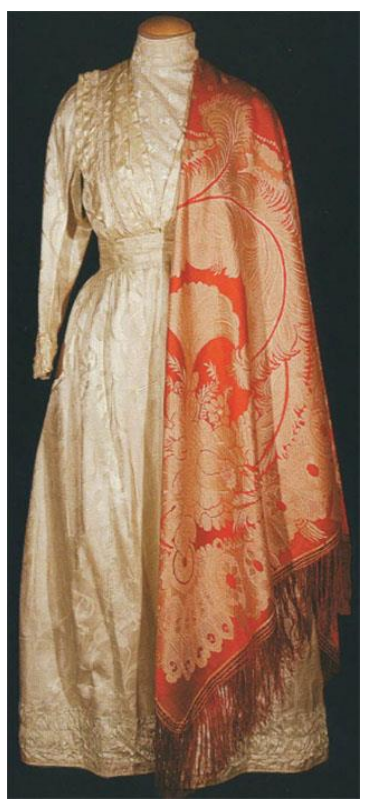

Figure 37. Wedding costume of a peasant woman, 'couple'. The early 20th century. Olonets Province, Kargopol County. It consists of a jacket and skirt, pale turquoise silk 'shtof

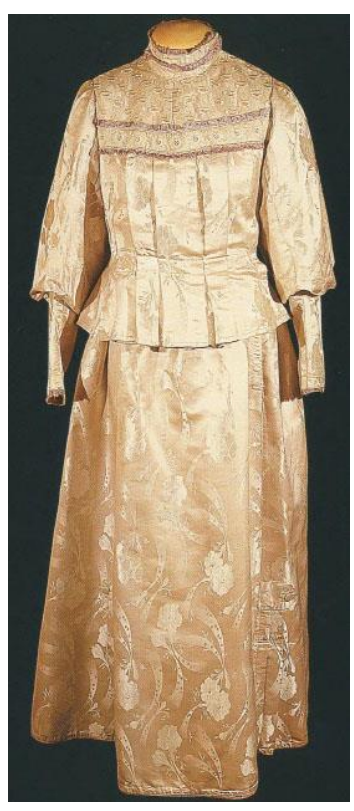

Figure 38. Festive women's costume. The early 20th century. Olonets

Province, Kargopol County. It consists of a 'seven-stitches' jacket and skirt, made of silk fabric with a lilac tint

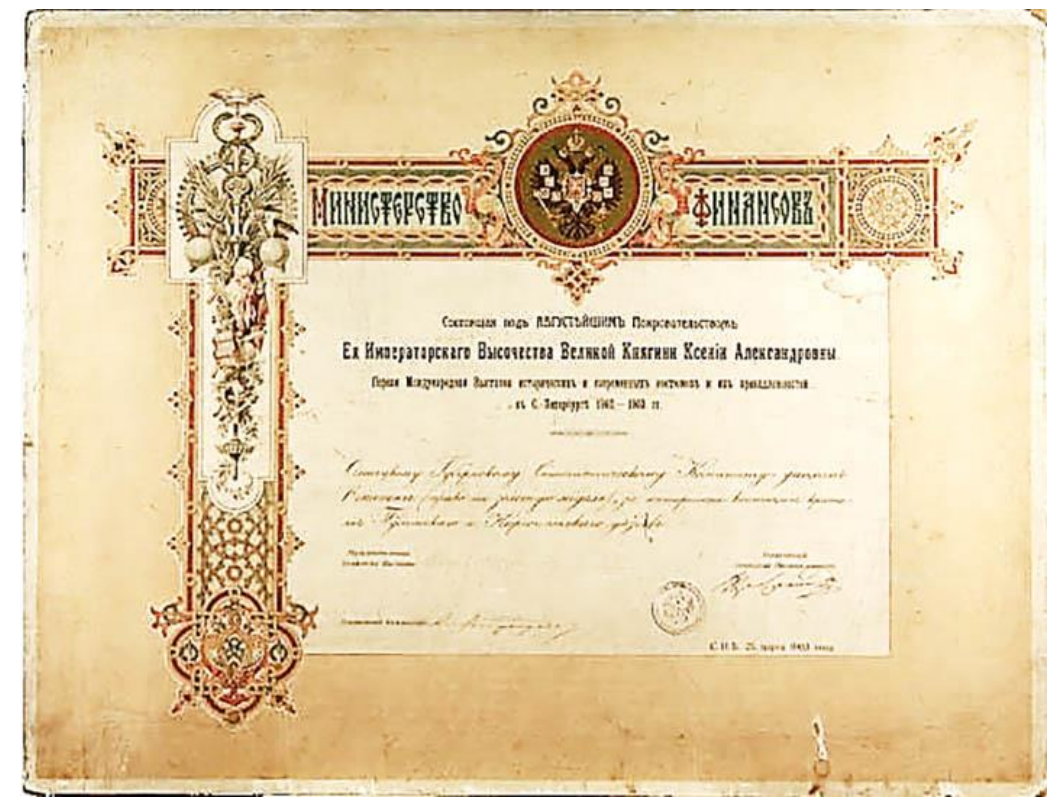

Figure 39. Diploma of the first degree to "the Olonets Provincial Statistical Committee for interesting costumes of peasants of Pudozh and Kargopol counties at the International Exhibition of Historical and Modern Costumes" in the Tauride

Palace in St Petersburg in 1902-1903. 


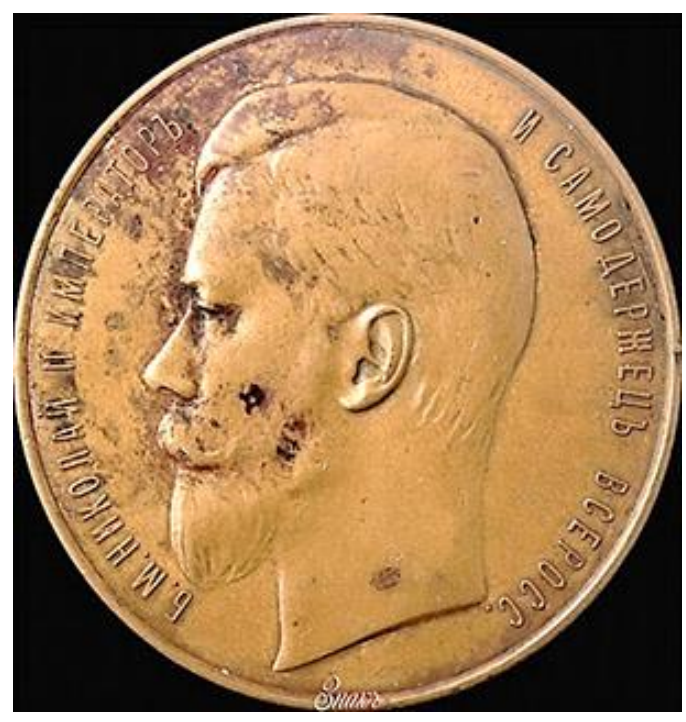

Figure 40. Gold Medal of the Statistical Committee for participation in the exhibition of historical costume in $\mathrm{St}$ Petersburg in 1902-1903. 